\title{
Age of the earliest transgressive event in the Krishna-Godavari Basin, India: evidence from dinoflagellate cysts and planktonic foraminifera biostratigraphy
}

\author{
Ashish Kumar Mishra ${ }^{1}$, Nallamuthu Malarkodi ${ }^{2}$, Arun Deo Singh ${ }^{3}$, Dinesh Babu ${ }^{4}$ and Vandana Prasad ${ }^{1 *}$
}

\begin{abstract}
A combined biostratigraphic study of dinoflagellate cysts and foraminifera was carried out on Early Cretaceous subsurface well cutting sediments from well A (DNG) (2800-2746 m depth) from the Krishna-Godavari Basin, India. The last appearance datum of marker species of dinoflagellate cysts and planktonic foraminifera was considered for the construction of the biostratigraphic framework. The study shows dominance of Early Cretaceous marker dinoflagellate cysts Cassiculosphaeridia magna, Cribroperidinium perforans, Hystrichodinium voigtii, Kleithriasphaeridium eoinodes, and planktonic foraminifera Hedbergella aptiana, Hedbergella mitra, Hedbergella praelippa, Hedbergella tardita, Microhedbergella miniglobularis and Hedbergella mitra species. In addition to this, the dinoflagellate cyst data were compared with the dinoflagellate biozones of Austral and Tethyan provinces. Based on earlier micropalaeontological records from the Krishna-Godavari Basin and the present study, a latest Barremian-early Aptian age has been determined for the earliest marine transgression in the Krishna-Godavari Basin. The early marine incursion during late Barremian-earliest Aptian in the Krishna-Godavari Basin compared to Albian age in Cauvery Basin suggests the opening of east coast from north to south.
\end{abstract}

Keywords: Biostratigraphy, Krishna-Godavari Basin, Palaeoenvironment

\section{Introduction}

The east coast of India was connected to Australia and Antarctica that separated from them during the Early Cretaceous which led to the opening of the eastern Indian Ocean (Fuloria et al. 1992; Fuloria 1993; Prabhakar 1993; Rangaraju et al. 1993; Kent et al. 2002; Lal et al. 2009; Gibbons et al. 2013). Despite the fact that a large number of studies on the tectonic evolution of the east coast of India have been carried out, no well-defined age for the opening of the Krishna-Godavari Basin has been proposed yet (Gibbons et al. 2013). The major constraint is the lack of well-preserved Early Cretaceous sediments and biostratigraphic framework from the eastern Indian margins (Prasad and Pundir 1999). The opening of the KrishnaGodavari Basin along the eastern part of India was a major event which contributed significantly in its development.

* Correspondence: prasad.van@gmail.com

${ }^{1}$ Birbal Sahni Institute of Palaeosciences, Lucknow, India

Full list of author information is available at the end of the article
The Krishna-Godavari Basin is a typical rift passive margin basin that evolved during the Late Jurassic period (Rao 2001; McLaughlin 2001). Though the India-Australia rifting can be roughly estimated to have begun in Early Cretaceous, the exact timing of marine incursion and the early opening history of east coast is not substantive (Gibbons et al. 2013). The Early Cretaceous outcrops along the fringe of western margins of the Krishna-Godavari Basin exist as patches and lack well-preserved fossils (Prasad and Pundir 1999). On the other hand, more or less complete stratigraphic records with well-preserved fossils can be found in the subsurface of the Krishna-Godavari Basin (Prasad and Pundir 1999). The presence of huge oil reserves in the Krishna-Godavari Basin prompted Oil India Limited and Oil and Natural Gas Corporation Ltd. (ONGC) to drill several exploratory wells in the region during the last two decades (Rao 2001). The Early Cretaceous sediments in the Krishna-Godavari Basin are underlain by Precambrian basement and pre-Cretaceous 
Gondwana sediments, and overlain by Deccan Traps (Prasad and Pundir 1999; Rao 2001). As evidenced from the Krishna-Godavari Basin deposits, early syn-rift sediments were deposited during early extensional tectonic subsidence accentuated by the earlier rifted fault systems located at the basement (Gupta 2006). Differential basin subsidence continued from Late Jurassic to Early Cretaceous along the basement bound fault system accommodating syn-rift sediments (Gupta 2006). The basin witnessed its first marine transgression during the Early Cretaceous (Prasad and Pundir 1999; Gibbons et al. 2013). Based on gravity and magnetic anomaly data (Powell et al. 1988; Veevers et al. 1991; Frey et al. 1996; Bryan et al. 1997; Kent et al. 2002), the India, Australia and Antarctica assembly was considered to have been fragmented around 136-124 Ma by the volcanic activity. But the incomplete biostratigraphic records, disparity in gravity and magnetic anomaly data and lack of preserved fossils lead to the existence of various controversial issues regarding tectonic movement of greater India. In order to provide a precise stratigraphic age to the first marine transgression in the Krishna-Godavari Basin, a detailed dinocyst and foraminifera based biostratigraphic study on well cutting samples of DNG well (Oil India Limited), Kakinada, KrishnaGodavari Basin was carried out. An attempt has also been made to compare the dinocyst biostratigraphic zones of Tethyan and Austral provinces. Finally, the palaeoenvironmental inference regarding the early rifting history of India-Australia was determined.

\section{Geology of study area}

The half-crescent shape Krishna-Godavari Basin is a pericratonic basin of a passive margin, situated on the east coast of India. The Krishna-Godavari Basin extends from Kakinada in the north to Nellore in the south. It covers about $15,000 \mathrm{~km}^{2}$ area onland and about 25,000 $\mathrm{km}^{2}$ area of offshore region (Prasad and Pundir 1999; Gupta 2006). It consists of $6000-8000 \mathrm{~m}$-thick sediments which correspond respectively from Early Permian to Recent in age. The Krishna-Godavari Basin sediments rest unconformably on highly metamorphosed Precambrian (Archean) basement (Fig. 1). The basin succession is divided into four groups viz. lower Gondwana Group (Chintalapudi Formation), Nizamapattanam Group, Gudivada Group and Vashishta Group (Table 1), each group being unconformably separated by the other. Gudivada Group of the basin is further subdivided into Raghavpuram Formation and Tirupati Formation. Raghavpuram shale which corresponded to Early Cretaceous (Barremian-Aptian to early Albian) in age, is well exposed at the western margin of the DwarkaTirumala town and unconformably overlies on Golapalli Sandstone. It has yielded mega fossils, plants, foraminifera and dinocysts (Prasad and Pundir 1999).

\section{Material and methods}

A total of 18 well cutting sediment samples were collected from 2800 to $2746 \mathrm{~m}$ depth of $54 \mathrm{~m}$ thick sequence of DNG well $\left(16^{\circ} 44^{\prime} \mathrm{N}, 82^{\circ} 04^{\prime} \mathrm{E}\right)$ drilled by Oil India Limited, near Kakinada, Andhra Pradesh, KrishnaGodavari Basin, east coast of India (Fig. 1). The samples are from Lower Cretaceous Raghavapuram Formation, and consisted of mostly shale with intermittent millimeter thin sandstone layers. The samples were analyzed for the study of foraminifera and dinoflagellate cysts.

For the study of organic-walled dinoflagellates, samples were processed according to the standard palynological methods (Tyson 1995). $10 \mathrm{~g}$ of sample were treated with $10 \%$ Hydrochloric acid $(\mathrm{HCl})$ to remove the carbonate. They were washed thoroughly with distilled water afterwards to remove the acid traces. Samples were then treated with $40 \%$ Hydrofluoric acid (HF) for $48 \mathrm{~h}$ to remove the silicates. Samples were washed thrice with distilled water to remove the acid remains and later, were treated with $10 \%$ Nitric acid $\left(\mathrm{HNO}_{3}\right)$ to mildly oxidize the organic matter. The residues are sieved through $15 \mu \mathrm{m}$ size. Permanent slides were prepared with polyvinyl alcohol and mounted with Canada balsam. Dinoflagellate cysts were scanned under $600 \mathrm{X}, 1000 \mathrm{X}$ magnification of Olympus Microscope BX53. Dinoflagellate cysts were scanned and identified based on published records (Cookson and Eisenack 1958; Davey 1966, 1974; Duxbury 1977; Backhouse 1988; Oosting et al. 2006; Brideaux, 1977; De Ren'eville \& Raynaud, 1981; Drugg, 1978; Ioannides et al, 1976; Lucas-Clark, 1984;).

For the study of foraminifera, samples were processed following standard micropaleontological procedures (Krumbein and Pettijohn 1938). The samples were disaggregated for microfossil separation by soaking $10 \mathrm{~g}$ of sample in $5 \%$ Hydrogen peroxide $\left(\mathrm{H}_{2} \mathrm{O}_{2}\right)$ for $24 \mathrm{~h}$ period. Soaked material was sieved with of $63 \mu \mathrm{m}$ size and dried at room temperature $\left(\sim 25-35^{\circ} \mathrm{C}\right)$. The washed residue was examined under $160 \mathrm{X}$ magnification of Leica M205C stereomicroscope. Microfossils were picked, identified based on morphology (Longoria 1974; Banner and Desai 1988; Banner et al. 1993) and mounted on faunal slides for a permanent record. Selected specimens were mounted on glass stub for Scanning electron microscope (SEM) and coated with platinum for microphotographing using an SEM (Jeol- JSM-7800F). All dinoflagellate cyst slides are stored in Birbal Sahni Institute of Palaeosciences (BSIP) museum (Locality no. 9622, Slide no. 16394-16406). The SEM images of foraminifera are illustrated in Fig. 2.

\section{Results}

The samples possessed well-preserved assemblages of dinocysts, pollen and spores. Amongst the palynomorphs, dinoflagellate cysts were dominant, whereas 


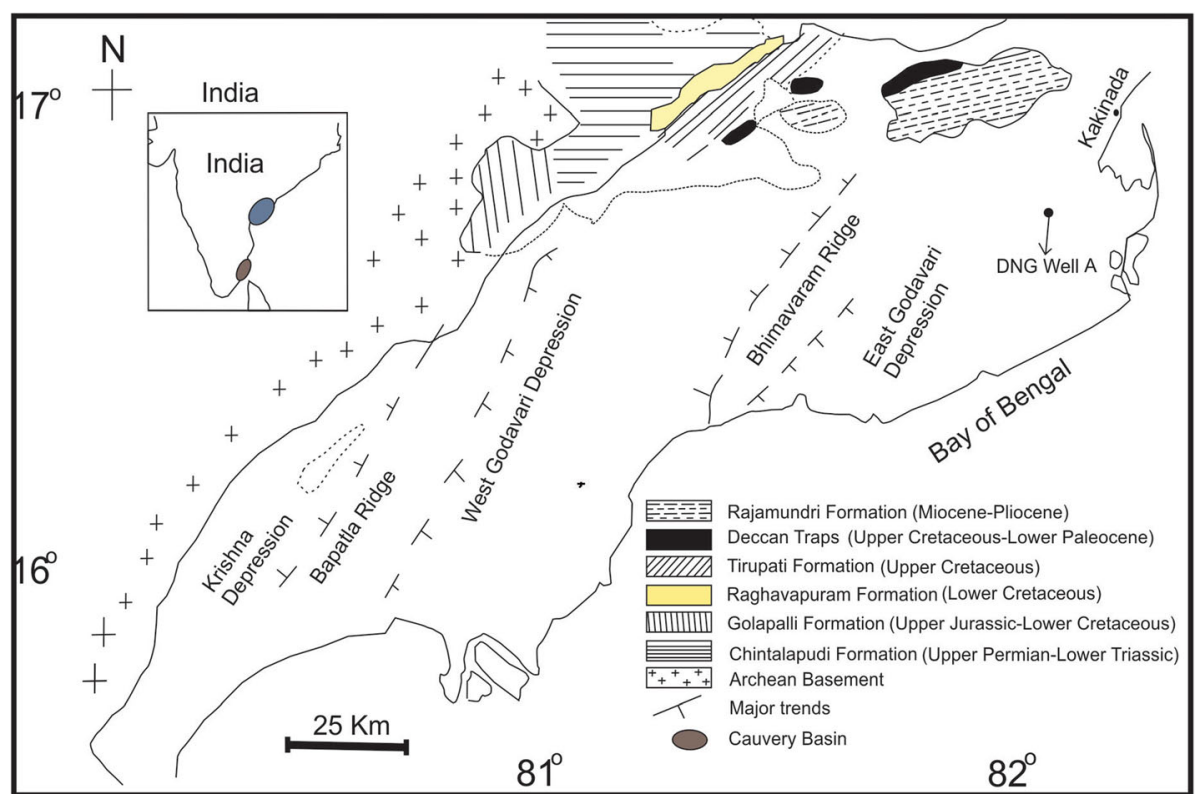

Fig. 1 Sketch showing location of the study area (modified from Chinnappa et al. 2014)

Table 1 Lithology, sedimentary environment and age of the Krishna-Godavari Basin, India (from Prasad and Pundir 1999)

\begin{tabular}{lll}
\hline GROUP FORMATION LITHOLOGY & AGE & SEDIMENTARY \\
ENVIRONMENT
\end{tabular}

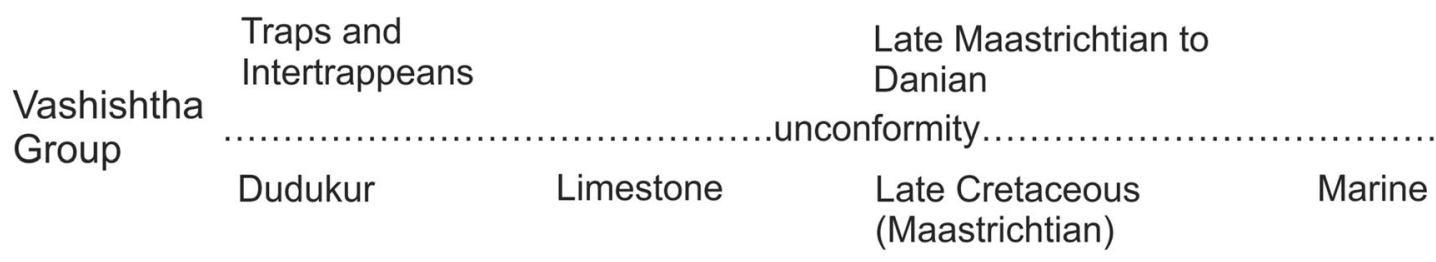

unconformity

\begin{tabular}{|c|c|c|c|c|}
\hline \multirow{3}{*}{$\begin{array}{l}\text { Gudivada } \\
\text { Group }\end{array}$} & Tirupati & Sandstone & $\begin{array}{l}\text { (Campanian to Early } \\
\text { Maastrichtian) }\end{array}$ & Shallow marine \\
\hline & & & nformity................. & \\
\hline & Raghavapuram & Shale & 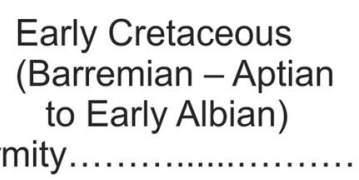 & Shallow marine \\
\hline $\begin{array}{l}\text { Nizama- } \\
\text { pattanam }\end{array}$ & Gollapali & Sandstone & $\begin{array}{l}\text { Early Cretaceous } \\
\text { (Neocomian) }\end{array}$ & Shallow Marine \\
\hline $\begin{array}{l}\text { Lower } \\
\text { Gondwana }\end{array}$ & Chintala................ & $\begin{array}{l}\ldots \ldots \ldots \ldots \ldots \\
\text { Sandstone }\end{array}$ & $\begin{array}{l}\text { mity................. } \\
\text { Late Permian }\end{array}$ & $\begin{array}{l}\text { Non Marine } \\
\text { (fluvial-to-lagoonal) }\end{array}$ \\
\hline \multicolumn{2}{|c|}{ Archean Basement } & Khondalite & Precambrian & \\
\hline
\end{tabular}



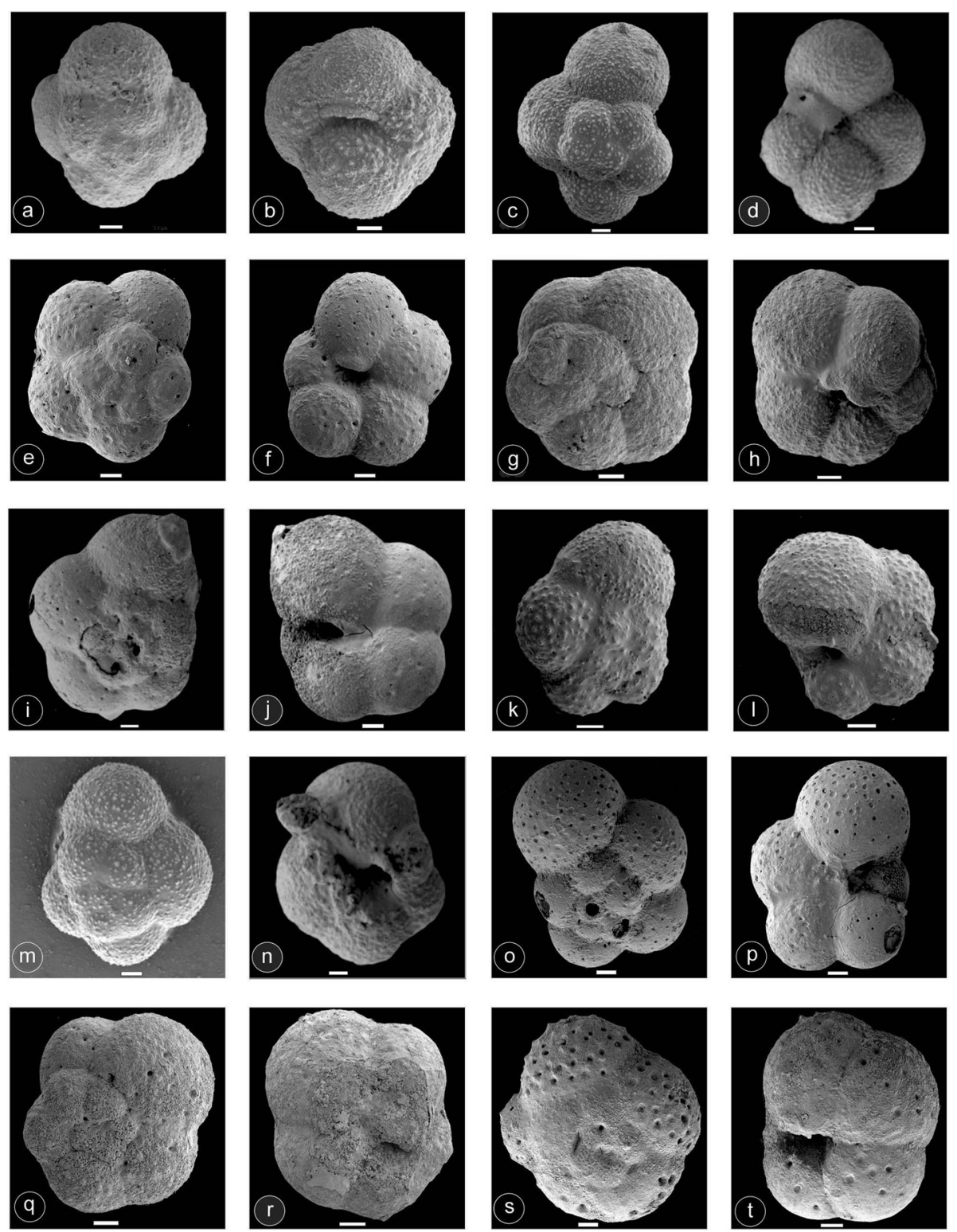

Fig. 2 SEM photograph of selected foraminiferal taxa from DNG well of the Krishna-Godavari Basin, India. a-b Hedbergella tardita. c-d Hedbergella ruka. e-f Hedbergella excelsa. $\mathbf{g}-\mathbf{h}, \mathbf{q}-\mathbf{r}$ Hedbergella gorbachikae. $\mathbf{i}-\mathbf{j}$ Hedbergella praelippa. k-I Hedbergella infracretacea. $\mathbf{m}-\mathbf{n}$ Microhedbergella miniglobularis. o-p Hedbergella aptiana. and s-t Hedbergella mitra, Scale bars represent $10 \mu \mathrm{m}$

pollen and spores were moderate to rare in numbers. A total of 10 samples were analyzed for the study of dinocysts. The diversity of dinoflagellate cysts was low to moderate in all the samples (Fig. 3). However, foraminifera were found with high diversity only in sample no. 444 at a depth interval of 2782-2785 m thick (Fig. 3).

\subsection{Dinoflagellate cyst biostratigraphy}

The assemblage consisted of 14 dinocyst species belonging to 12 genera viz. Cassiculosphaeridia magna, Cleistosphaeridium aciculare, Cribroperidinium edwardsii, Cribroperidinium perforans, Cyclonephelium distinctum, Dinopterygium dimorphum, Hystrichodinium voigtii, Hystrichosphaeridium tubiferum, Kleithriasphaeridium eoinodes, Litosphaeridium conispinum, Odontochitina operculata, Oligosphaeridium complex, Oligosphaeridium pulcherrimum and Polysphaeridium duma (Fig. 4). Among these, the dominant species were Cribroperidinium edwardsii, Polysphaeridium duma, Cassiculosphaeridia magna, Oligosphaeridium complex and Cribroperidinium perforans. In the present study, first occurrence (FO) of Hystrichosphaeridium tubiferum and Oligosphaeridium pulcherrimum was recorded at depth of $2797 \mathrm{~m}$ while their last occurrence (LO) was found at depth of $2794 \mathrm{~m}$ (Fig. 3). FO of Cassiculosphaeridia magna, 


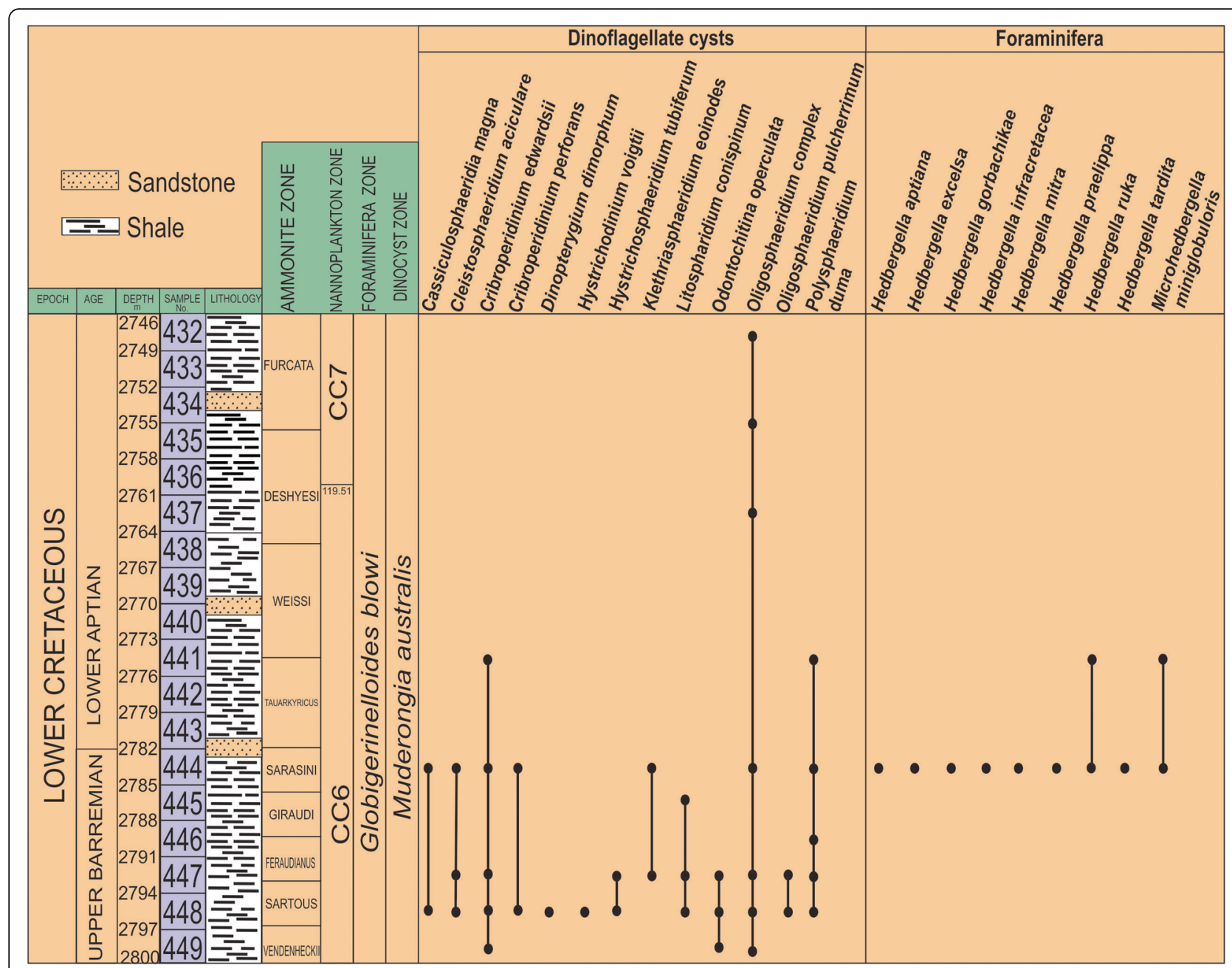

Fig. 3 Graph showing FO and LO of selected dinoflagellates cyst and foraminiferal taxa from DNG well, Krishna-Godavari Basin, India

Cribroperidinium perforans and Cleistosphaeridium aciculare was recorded at depth of $2797 \mathrm{~m}$ and their LO was found at depth of $2782 \mathrm{~m}$. Cribroperidinium edwardsii which occurred abundantly in the succession was found to appear first at depth of $2800 \mathrm{~m}$ of the succession while its LO was recorded at depth of $2773 \mathrm{M}$. FO and LO of Kleithriasphaeridium eoinodes were found at depth of $2797 \mathrm{~m}$ and $2791 \mathrm{~m}$, respectively. FO of Litosphaeridium conispinum was recorded at depth of $2794 \mathrm{~m}$ and its LO was found at depth of $2785 \mathrm{~m}$. FO of Odontochitina operculata was recorded at the depth of $2800 \mathrm{~m}$ and its LO occurred at the depth of $2791 \mathrm{M}$. FO of Polysphaeridium duma was found at depth of $2797 \mathrm{~m}$ and its LO was recorded at 2773 $\mathrm{m}$. Oligosphaeridium complex was found in large numbers at depth $2797 \mathrm{~m}$ and $2749 \mathrm{~m}$.

\subsection{Comparison of dinoflagellate cyst species}

Cassiculosphaeridia magna, recorded in the sediments (Fig. 5a-c), differs from Cassiculosphaeridia reticulata in having a large sized cyst. Cribroperidinium perforans recorded at a depth of $2797 \mathrm{~m}$ (Fig. 5f), showed characteristic feature of thin perforated wall of theca and well developed bluntly pointed horn with distinct helicoid girdle. Cribroperidinium species (Fig. 5d-e) consisted of prominent long horn, precingular archeopyle, girdle helicoid, finely granular plates with pointed spines especially in apical and antapical region and hence was placed in Cribroperidinium edwardsii. Hystrichosphaeridium species having apical archeopyle with serrated processes tip (margin) was placed under Hystrichosphaeridium tubiferum (Fig. 5g-h). Dinoflagellate species placed under Kleithriasphaeridium eoinodes (Fig. $5 \mathrm{i}-\mathrm{j}$ ) bear strong ribbed tubular processes with denticulate margin and precingular archeopyle. Apical archeopyle, rounded antapex, non tabular, open processes of various length, width and shape are shown by Cyclonephelium distinctum (Fig. 6a-c).

\subsection{Foraminifera biostratigraphy}

The samples yielded nine species of well-preserved planktonic foraminifera viz., Hedbergella aptiana, 


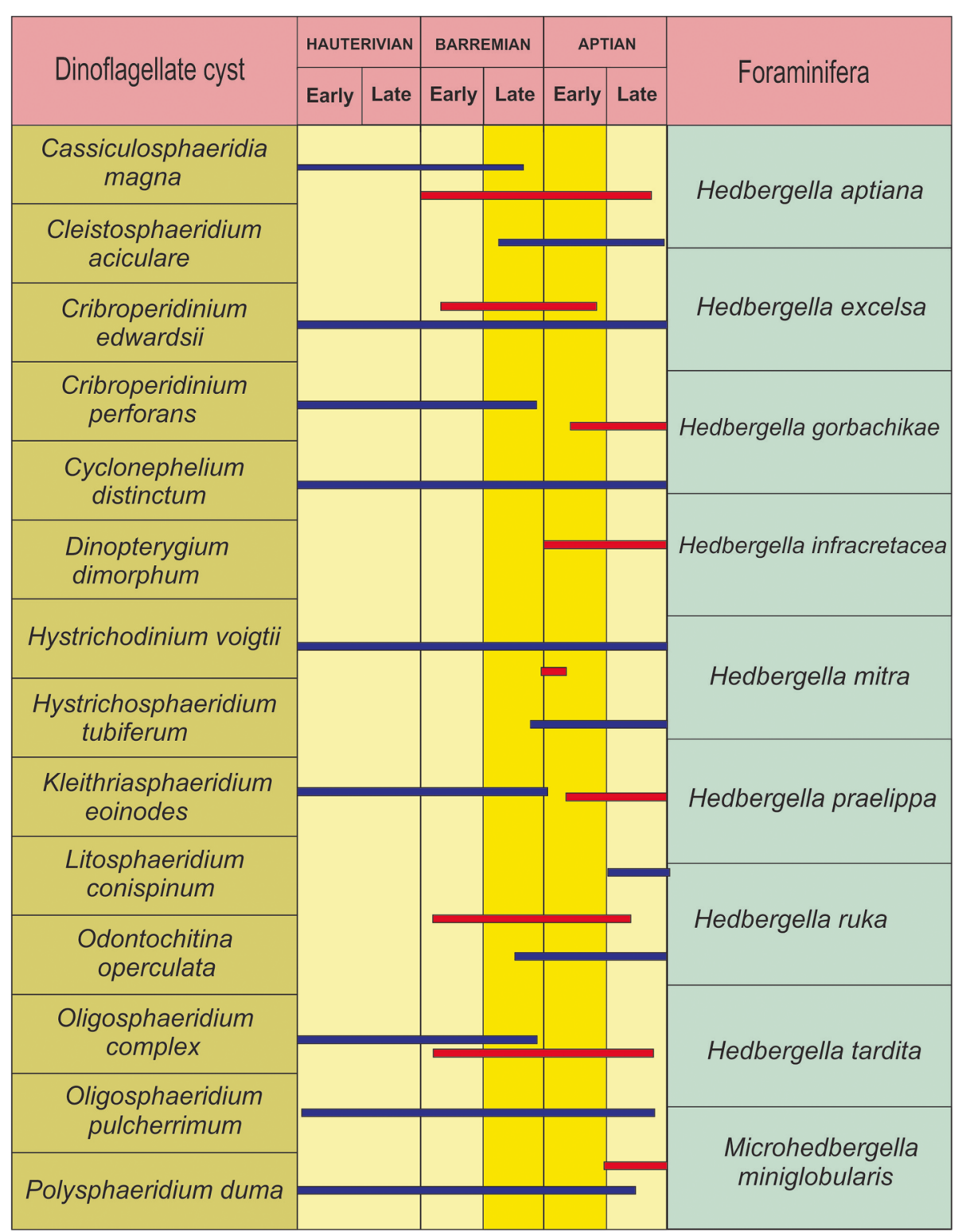

Fig. 4 Range chart of recorded dinoflagellate cysts and foraminifera of Early Cretaceous age

Hedbergella excelsa, Hedbergella gorbachikae, Hedbergella infracretacea, Hedbergella mitra, Hedbergella praelippa, Hedbergella ruka, Hedbergella tardita, and Microhedbergella miniglobularis (Fig. 4). The depth interval ranging from 2782 to 2785 m contains Hedbergella ruka and Hedbergella excelsa (the index taxa). The taxa range from Late Barremian to early Aptian age (Brovina, 2017). The species of Hedbergella aptiana, Hedbergella tardita and Microhedbergella miniglobularis were also recovered from the succession of the same interval indicating Early Cretaceous (late Barremianearly Aptian) age (Figs. 3, 4). Besides, this interval also yielded Hedbergella praelippa assigning an early Aptian age. Hedbergella ruka was also recognized in the G. blowi Zone (Brovina 2017). Globigerinelloides blowi, a marker species of G. blowi Zone was absent in the present study.

The ranges of planktonic species identified from the studied section are presented in Fig. 4. It is evident from the range chart that a large number of first and last occurrences of foraminifera are recorded in the succession. These species have been previously recognized on a global basis and thus form valuable stratigraphic markers. Index foraminifera which are necessary for precise age assignment were discovered from the succession, namely Hedbergella excelsa and H. ruka. Although the assemblage as a whole indicates late Barremian-early Aptian age, late Barremian to early Aptian part of succession is 

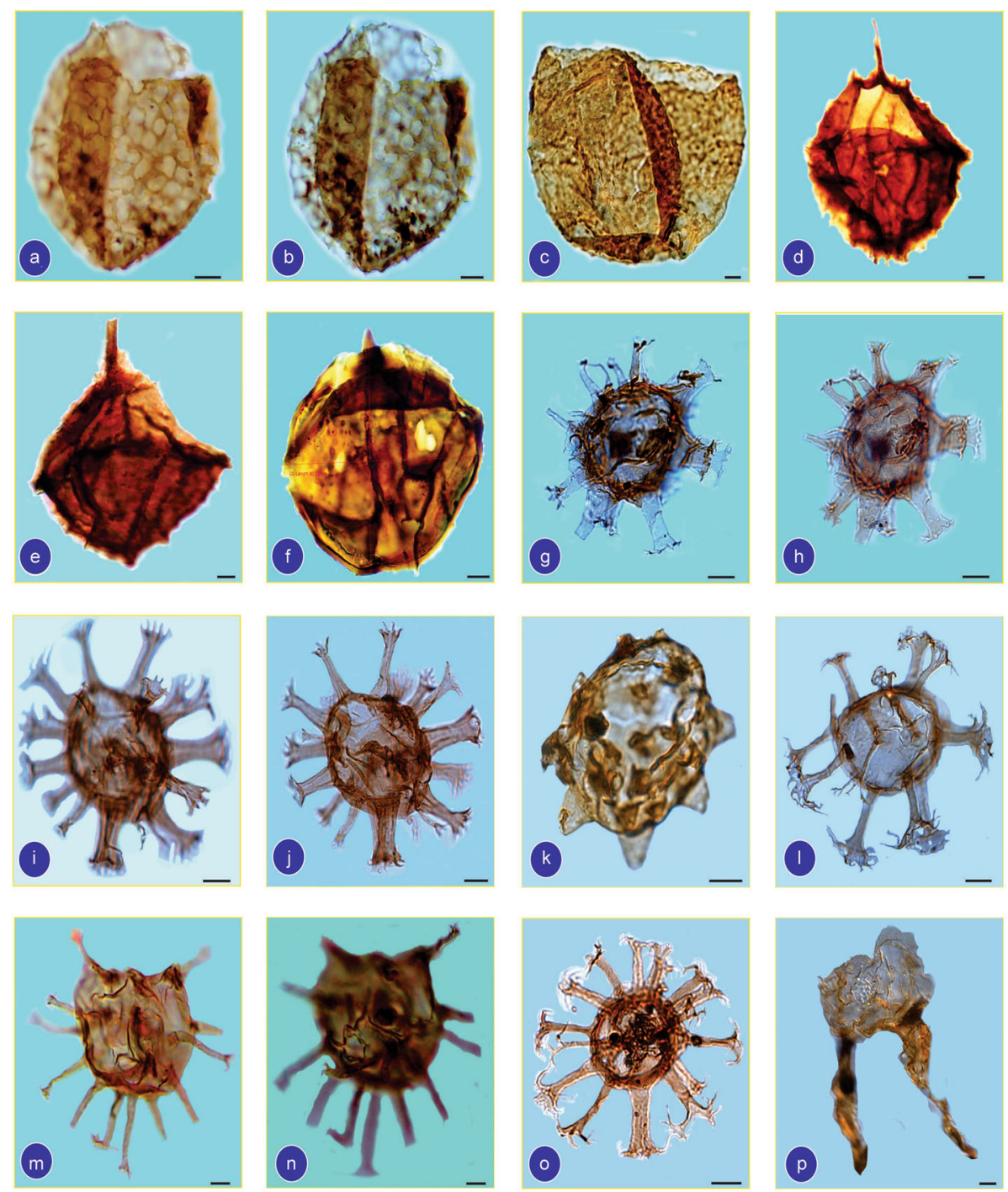

Fig. 5 Light microscopic photographs of selected taxa from DNG well of the Krishna-Godavari Basin, Kakinada, India. a-c Cassiculosphaeridia magna, BSIP-16395(A, B), 16394(C), EFC 21D/4 (A, B), 20 M/1(C). d-e Cribroperidinium edwardsii, Dorsal view BSIP-16395, EFC 20 L/1(D), 34 V/2 (E). f ventral view of Cribroperidinium perforans, BSIP-16397, EFC 21 W. g-h Hystrichosphaeridium tubiferum, BSIP-16398, EFC 13O/4; i-j Kleithriasphaeridium eoinodes, BSIP-16400, EFC 41 N. k Litosphaeridium conispinum, BSIP-16399, EFC 25E/1. I Oligosphaeridium pulcherrimum, BSIP16401, EFC 17G. m-o Oligosphaeridium complex, BSIP-16400(M, N), 16402(O), EFC 39F (M, N), 25 M/3. p Odontochithina operculata, BSIP-16404, EFC 45P/2. Scale bars represent $10 \mu \mathrm{m}$ and EFC Represents England Finder Coordinates

characterized by the presence of long-ranging planktonic species such as Hedbergella aptiana, Hedbergella ruka, Hedbergella excelsa and Hedbergella mitra. These species have been recorded in late Barremian to early Aptian sediments from different parts of the world as well (Banner et al. 1993; Banner and Desai 1988; Longoria 1974) (Fig. 4).

\section{Palaeoenvironment}

On the basis of published record, paleotectonic events and palaeoenvironment of the east coast of India (especially the Krishna-Godavari Basin and Cauvery Basin) remain open to discussion. The opening of the Krishna-
Godavari Basin either from north to south (Powell et al. 1988; Frey et al. 1996; Gibbons et al. 2013; Chatterjee et al. 2017) or from south to north (Singh and Swamy 2006) still continues to be debatable. The sequence examined here corresponds to late Barremian-early Aptian age and supports the direction of opening of the basin from north to south because the Cauvery Basin opened in Albian time (Nagendra et al. 2011) which is situated towards the south of the Krishna-Godavari Basin. Sample no. 444 (depth ranging from 2782 to $2785 \mathrm{~m}$ ) of DNG well yielded high diversity of dinoflagellate cysts and foraminifera, thus providing evidence for the first transgressive event and open marine conditions during 

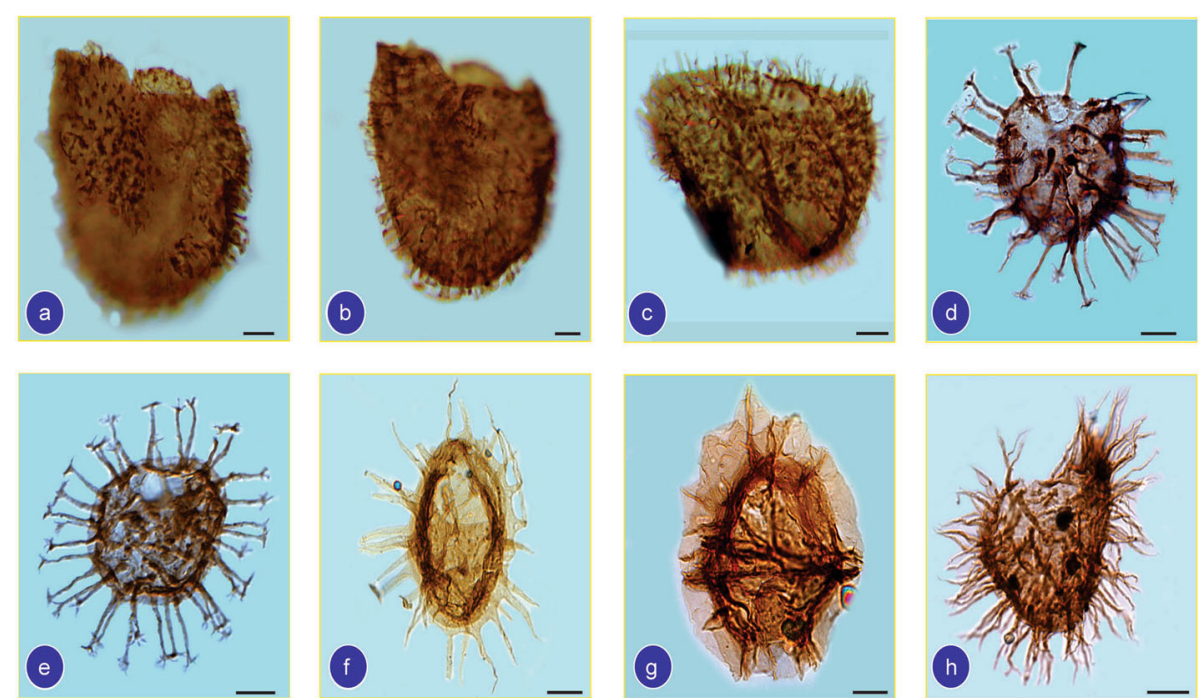

Fig. 6 Light microscopic photographs of selected taxa from DNG well of the Krishna-Godavari Basin. a-c Cyclonephelium distinctum, BSIP-16403, EFC 32O/2(A, B), 35 T/4(C). d-e Polysphaeridium duma, BSIP-16403(D), 16401(E), EFC 42E/3(D), 20F/2(E). f Hystrichodinium voigtii, BSIP-16399, EFC 16 L/4. g Dinopterygium dimorphum, BSIP-16397, EFC 29G/4. h Cleistosphaeridium aciculare, BSIP-16406, EFC 42S; Scale bars represent 10 4m and EFC Represents England Finder Coordinates

late Barremian-early Aptian in the Krishna-Godavari Basin.

\section{Discussion and conclusions}

The Krishna-Godavari Basin is a pericratonic basin which was formed during Hauterivian to Albian period following the fragmentation of Gondwanaland (Garg and Jain 1987; Prasad, and Pundir 1999). The lack of early records of marine transgression in the Krishna-Godavari Basin is attributed to the absence of Early Cretaceous outcrops from the region. Most of the Early Cretaceous sedimentary successions in the Krishna-Godavari Basin are under a thick pile of deltaic sediments and hence subsurface study remains the only alternative. A broad biostratigraphic framework based on foraminiferal biostratigraphy is available from the region (Bhalla 1965, 1969). While few dinoflagellate cysts based biostratigraphic studies provided broad Barremian-Albian age to the Krishna-Godavari Basin (Garg and Jain 1987; Prasad, and Pundir 1999). In the present study the dinocyst and planktonic foraminifera records from DNG well provide significant data for carrying out biostratigraphic study of the Krishna-Godavari Basin. Despite the problems of reworking and contamination in well cuttings, the age of the earliest marine transgression event of the Krishna-Godavari Basin can be determined with some confidence. Based on the FO and LO of some marker species of dinoflagellate cysts and planktonic foraminifera and their comparison with global marker species, Early Cretaceous biostratigraphic framework of the Krishna-Godavari Basin has been proposed. Dinoflagellate cysts have been prominently used in the correlation of marginal marine Early Cretaceous sequences of Austral region and based on that, a biostratigraphic framework has been given (Morgan 1979; Helby 1987; Backhouse 1988). However the dinoflagellate zonal schemes of the Austral and Tethys region are different, due to which some variations can be seen in the taxonomic identification of dinoflagellate cysts and their geological ranges (Oosting et al. 2006). The geological range of Cassiculosphaeridia magna is early Barriasian to late Barremian (Costa et al. 1992; Stover et al. 1996) while it is early Barremian in England, (Davey 1974) and early Aptian in western Australia (Fig. 7). Hystrichodinium voigtii was recorded in the late Valanginian to early Hauterivian in Poland (Alberti 1961) whereas the same species is defined and assigned different ages in different places: early to late Hauterivian in England (Costa et al. 1992), Barremian to Turonian in Germany, Barriasian to Barremian in England (Alberti 1961; Davey et al. 1969; Duxbury 1977; Sarjeant 1966) (Fig. 7). Litosphaeridium conispinum stratigraphically ranges from late Aptian to Cenomanian (Stover et al. 1996) while the same species is reported in England from late Albian to Cenomanian (Cookson and Hughes 1964) and from late Albian in France and England (Davey and Verdier 1973; Costa et al. 1992). Similarly, the geological range of Cyclonephelium distinctum is Kimmeridgian to Cenomanian in England (Stover et al. 1996) while the same species has been defined from Hauterivian to early Aptian in France (Millioud 1969), from late Barremian to Aptian in Canada (Jansonius 1986) and Senonian (upper Cretaceous) in western Australia (Deflandre and Cookson, 1955). Polysphaeridium duma is reported from 


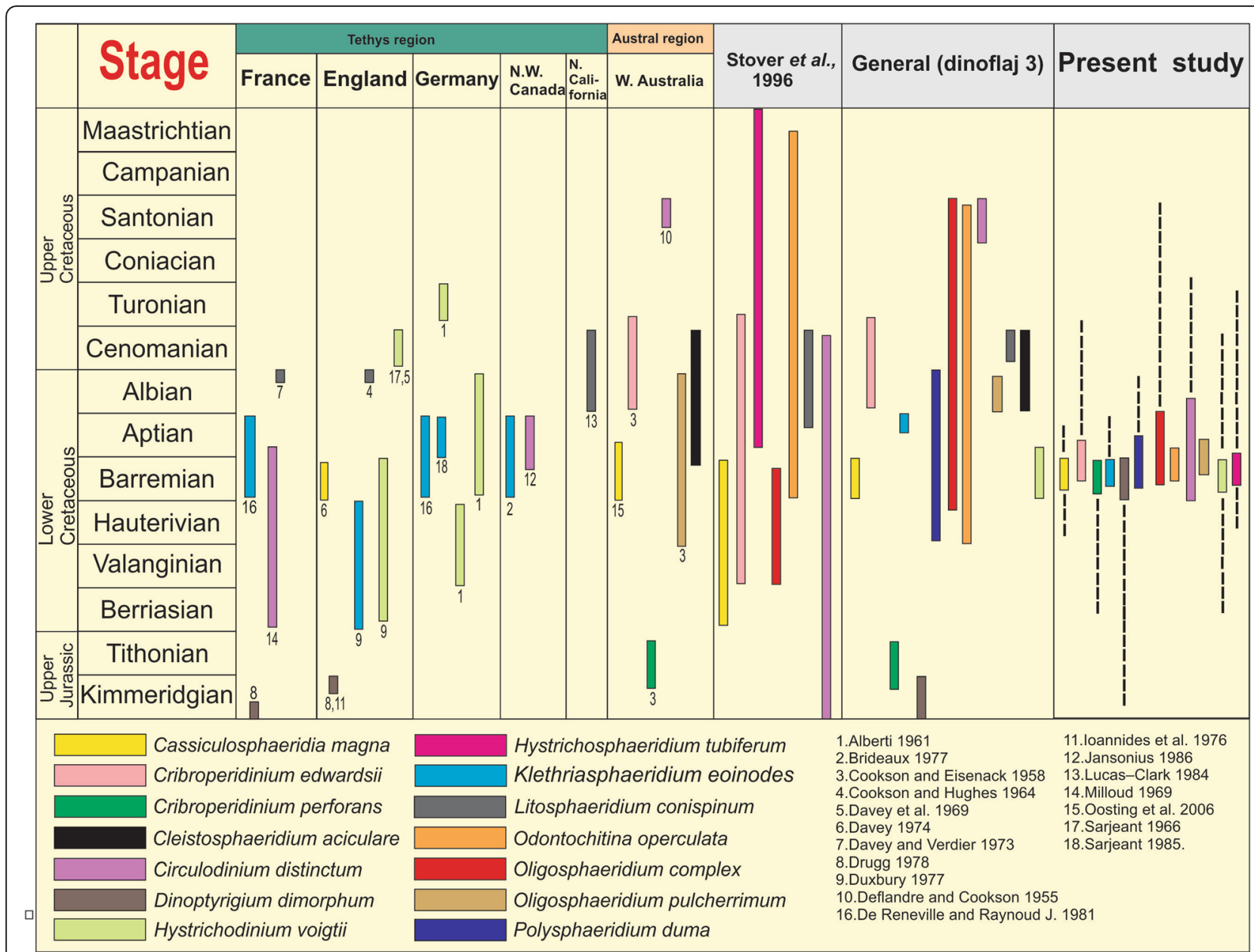

Fig. 7 Chart showing correlation of dinoflagellate cyst records between DNG well (present study) samples, Austral and Tethys region, black dotted line represents inferred boundary age

Hauterivian to Albian (Below 1982). Cribroperidinium edwardsii is reported from early Valanginian to early Turonian in France (Stover et al. 1996) (Fig. 7), early to late Cenomanian in England (Costa et al. 1992) and from Albian to early Turonian in England (Burger 1980). Cribroperidinium perforans is recorded from late Jurassic to Barremian in western Australia (Cookson and Eisenack 1958), in early Barremian from England (Davey 1974) and in early Aptian from western Australia (Oosting et al. 2006). As depicted in Fig. 2, Odontochitina operculata is described under O. operculata Zone (Oosting et al. 2006) and O. operculata- Muderongia australis Zone (Prasad and Pundir 1999). Some species like Oligosphaeridium pulcherrimum and those belonging to Oligosphaeridium complex are also placed under Odontochitina operculataMuderongia australis zone (Prasad and Pundir 1999). The present dinocysts range from the DNG well, KrishnaGodavari Basin compares well with the Early Cretaceous ranges of Tethyan and Austral regions. The FO and LO of dinoflagellate cysts from the lower part of the succession (2797-2773 m of depth) of the DNG well compares well with the upper part of the Muderongia australis Zone (Stover and Helby 1987; Oosting et al. 2006) and lower part of the Odontochitina operculata Zone (Helby 1987) suggesting an age of late Barremian-early Aptian for the basal-most part of the succession (Fig. 7).

Foraminiferal data of the depth interval ranging from 2782 to 2785 m consists Hedbergella aptiana, Hedbergella gorbachikae, Hedbergella infracretacea, Hedbergella praelippa, Hedbergella tardita, and Microhedbergella miniglobularis suggesting an age of late Barremian-early Aptian. This interval also yielded Hedbergella praelippa and Hedbergella mitra foraminifera assigning an early Aptian age. Planktonic foraminifera species, namely Hedbergella excelsa and Hedbergella ruka (the index taxa) of late Barremian-early Aptian (Brovina 2017) is reported from 2782 to $2785 \mathrm{~m}$ in DNG well. The ranges of planktonic species identified from the section are 
presented in Fig. 4. These species have been previously recognized on a global basis and thus form valuable stratigraphic markers. Based on the foraminifera and dinoflagellate biostratigraphy, the basal part of the DNG well corresponds to latest Barremian-early Aptian age.

\section{Abbreviations}

DNG: Well 'A' near Kakinada, Andhra Pradesh, Krishna-Godavari Basin, east coast of India; FO: First occurrence; LO: Last occurrence; O: Odontochitina SEM: Scanning Electron Microscope

\section{Acknowledgements}

We are thankful to Director, BSIP for providing necessary facilities to carry out the present study. This study is carried out as a part of MoES funded Project No. (Geo Sci) 36/2014 and authors are grateful to S K Jena, Oil India Limited for his recommendation in providing the samples. Help and suggestions from Prof. I. B. Singh (Lucknow University), Prof. R. Mark Leckie (University of Massachusetts) is duly acknowledged. Authors are grateful to Dr. Biswajeet Thakur, Dr. Prem Raj Uddandam, Mahi Bansal, Chethan Kumar, C.S. Bhargava, Shubhash Chandra Somappa for their help and support in this study.

\section{Authors' contributions}

AKM processed all the samples, analyzed and interpreted the present study data and prepared this manuscript. NM performed the foraminiferal morphology examination and helped to prepare their stratigraphic ranges. ADS reconstructed the palaeoenvironment of foraminifera in the present study and checked the manuscript thoroughly. DB has helped in the sample procurement and provided the lithological details and interpretations. VP designed the research problem and contributed major part in identification of dinoflagellate cyst and reconstruction of the paleoenvironment in the study. All authors read and approved the final manuscript.

\section{Funding}

The present study has been funded By Ministry of Earth Science, Govt. of India under the sponsored project no. MoES Geo.Sci. (Po/36/2014).

\section{Availability of data and materials}

The dinoflagellate cyst and foraminiferal slides have been deposited in the museum of Birbal Sahni Institute of Palaeosciences (Locality no. 9622, Slide no. 16394-16406). The data and other details of this study are available with the corresponding author Dr. Vandana Prasad and upon request all the data and slides can be made available.

\section{Competing interests}

The authors declare that they have no competing interests.

\section{Author details}

${ }^{1}$ Birbal Sahni Institute of Palaeosciences, Lucknow, India. ${ }^{2}$ Department of Geology, Jnanabharathi Campus, Bangalore University, Bengaluru 560056, India. ${ }^{3}$ Department of Geology, Banaras Hindu University, Varanasi 221005, India. ${ }^{4}$ Oil India Limited, Kakinada, India.

\section{Received: 8 February 2019 Accepted: 23 December 2019}

\section{0.}

\section{References}

Alberti, G. 1961. Zur kenntnis mesozoischer und altterti"arer dinoflagellaten und-hystrichosphaerideen von nord-und mitteldeutschland sowie einigen anderen europ"aischen gebieten. Palaeontographica Abteilung $A$ 116: 1-58.

Backhouse, J. 1988. Late Jurassic and early Cretaceous palynology of the Perth Basin. Western Australia. Bulletin of Geological Survey of Western Australia 135: 1-233 State Print Division.

Banner, F.T., P. Copestake, and M.R. White. 1993. Barremian-Aptian Praehedbergellidae of the North Sea area: A reconnaissance. Bulletin of the Natural History Museum, Geology Series 49 (1): 1-30.

Banner, F.T., and D. Desai. 1988. A review and revision of the Jurassic-early cretaceous Globigerinina, with especial reference to the Aptian assemblages of Speeton (North Yorkshire, England). Journal of Micropaleontology 7 (2): 143-185. https://doi.org/10.1144/jm.7.2.143.

Below, R. 1982. Dinoflagellate cysts from Valanginian to lower Hauterivian sections near ait hamouch, Morocco. Revista espãnola de micropaleontolog'ia 14 (1-3): 23-52.

Bhalla, S.N. 1965. New species of foraminifera from the Raghavapuram shales (lower cretaceous), Andhra Pradesh, India. Bulletin of the Geological Society of India 2 (2): 39-43.

Bhalla, S.N. 1969. Foraminifera from the type Raghavapuram shales, east coast Gondwanas, India. Micropaleontology 15 (1): 61-84. https://doi.org/ $10.2307 / 1484860$.

Brideaux, W.W. 1977. Taxonomy of upper Jurassic-lower cretaceous microplankton from the Richardson Mountains, district of Mackenzie, Canada. Bulletin of the Geological Survey of Canada 281: 1-89.

Brovina, E. 2017. Planktonic foraminiferal biostratigraphy of the upper Barremian and Aptian of crimea. Stratigraphy and Geological Correlation 25 (5): 515-531. https://doi.org/10.1134/\$086959381705001X.

Bryan, S., A. Constantine, C. Stephens, A. Ewart, R. Sch"on, and J. Parianos. 1997. Early cretaceous volcano-sedimentary successions along the eastern Australian continental margin: Implications for the break-up of eastern Gondwana. Earth and Planetary Science Letters 153 (1-2): 85-102.

Burger, D. 1980. Early cretaceous (Neocomian) microplankton from the Carpentaria basin, northern Queensland. Alcheringa 4 (4): 263-279. https://doi.org/10.1080/03115518008558971.

Chatterjee, S., C.R. Scotese, and S. Bajpai. 2017. The restless Indian plate and its epic voyage from Gondwana to Asia: Its tectonic, paleoclimatic, and paleobiogeographic evolution. Geological Society of America Special Paper 529: 1-147.

Chinnappa, C., A. Rajanikanth, and Y. Rao. 2014. Floral diversity and implications in palaeoenvironment of Vemavaram formation, KrishnaGodavari Basin, India. The Face of Climate Change Palaeobotanist 63 (1): 63-78.

Cookson, I.C., and A. Eisenack. 1958. Microplankton from Australian and new Guinea upper mesozoic sediments. In Proceedings of the Royal Society of Victoria (New Series) 70: 19-79.

Cookson, I.C., and N. Hughes. 1964. Microplankton from the Cambridge greensand (mid cretaceous). Palaeontology 7: 37-59.

Costa, L.I. and R.J. Davey. 1992. Dinoflagellate cysts of the Cretaceous system. In A stratigraphic index of dinoflagellate cysts, ed. A.J. Powell, 99-153. London: British Micropalaeontological Society Publication Series.

Davey, R., and J.P. Verdier. 1973. An investigation of microplankton assemblages from latest Albian (vraconian) sediments. Revista Espanola de Micropaleontologia 5 (2): 173-212.

Davey, R.J. 1966. Generic reallocations. Appendix to studies on Mesozoic and Cenozoic dinoflagellate cysts. British Museum (Natural History) Geology, Bulletin, Supplement 3: 4-248.

Davey, R.J. 1974. Dinoflagellate cysts from the Barremian of the Speeton clay, England. In Symposium on stratigraphic palynology. Birbal Sahni Institute of Palaeobotany, Special Publication, vol. 41, 75.

Davey, R.J., C. Downie, W.A.S. Sarjeant, G.L. Williams, and L.A. Krukewich. 1969 Studies on Mesozoic and Cainozoic Dinoflagellate cysts; with appendix i. British Museum (Natural History) Geology, Bulletin, Supplement 3: 9-248.

De Ren'eville, P., and J. Raynaud. 1981. Palynologie du stratotype du barr'emien. Bull Cent Rech Explor Prod Elf Aquitaine 5: 1-29.

Deflandre, G., and I.C. Cookson. 1955. Fossil microplankton from Australian late mesozoic and tertiary sediments. Marine and Freshwater Research 6 (2): 242-314. https://doi.org/10.1071/MF9550242.

Drugg, W. 1978. Some Jurassic dinoflagellate cysts from England, France and Germany. Palaeontographica Abteilung B 168 (1-3): 61-79.

Duxbury, S. 1977. A palynostratigraphy of the Berriasian to Barremian of the speeton clay of speeton, England. Palaeontographica Abteilung B 160 (1-3): $17-67$.

Frey, F.A., N.J. McNaughton, D.R. Nelson, and R.A. Duncan. 1996. Petrogenesis of the Bunbury basalt, Western Australia: Interaction between the Kerguelen plume and Gondwana lithosphere? Earth and Planetary Science Letters 144 (1-2): 163-183. 
Fuloria, R. 1993. Geology and hydrocarbon prospect of Mahanadi Basin India. In Proceedings of second Seminar on Petroliferous Basins in India, vol. 1, 355-370. Dehradun: Indian Petroleum Publication.

Fuloria, R., R. Pandey, B. Bharali, and J. Mishra. 1992. Stratigraphy, structure and tectonics of Mahanadi offshore basin. Geological Survey of India Special Publication 29: 255-265.

Garg, R., and K.P. Jain. 1987. Jurassic and lower cretaceous dinoflagellate cysts from India with some remarks on the concept of upper Gondwana. Palaeobotanist 36: 254-268.

Gibbons, A.D., J.M. Whittaker, and R.D. Muller. 2013. The breakup of east Gondwana: assimilating constraints from Cretaceous ocean basins around India into a best-fit tectonic model. Journal of Geophysical Research: Solid Earth 118 (3): 808-822. https://doi.org/10.1002/jgrb.50079.

Gupta, S.K. 2006. Basin architecture and petroleum system of KrishnaGodavari Basin, east coast of India. The Leading Edge 25 (7): 830-837. https://doi.org/10.1190/1.2221360.

Helby, R. 1987. Muderongia and related dinoflagellates of the latest Jurassic to early cretaceous of Australasia. Memoir of the Association of Australasian Palaeontologists 4: 1-336 Title of the page "studies in Australian Mesozoic palynology".

Ioannides, N., G. Stavrinos, and C. Downie. 1976. Kimmeridgian microplankton from Clavell's hard, Dorset, England. Micropaleontology 22 (4): 443-478. https://doi.org/10.2307/1485174.

Jansonius, J. 1986. Reexamination of mesozoic Canadian dinoflagellate cysts published by saj pocock (1962, 1972). Palynology 10 (1): 201-223. https://doi.org/10.1080/01916122.1986.9989309.

Kent, R.W., M.S. Pringle, R.D. M"uller, A.D. Saunders, and N.C. Ghose. 2002. ${ }^{40} \mathrm{Ar} /{ }^{39} \mathrm{Ar}$ geochronology of the Rajmahal basalts, India, and their relationship to the Kerguelen plateau. Journal of Petrology 43 (7): 1141-1153. https:/doi.org/10.1093/petrology/43.7.1141.

Krumbein, W.C., and F.J. Pettijohn. 1938. Manual of sedimentary petrography, 549. New York: D. Appleton-century company.

Lal, N.K., A. Siawal, and Anil K. Kaul. 2009. Evolution of east coast of India-A plate tectonic reconstruction. Journal of the Geological Society of India 73 (2): 249-260. https://doi.org/10.1007/s12594-009-0081-1.

Longoria, J.F. 1974. Stratigraphic, morphologic and taxonomic studies of Aptian planktonic foraminifera. Empresa Nacional" Adaro" Publication, 1-150.

Lucas-Clark, J. 1984. Morphology of species of Litosphaeridium (cretaceous, dinophyceae). Palynology 8 (1): 165-193. https://doi.org/10.1080/ 01916122.1984 .9989276$.

McLaughlin, S. 2001. The breakup history of Gondwana and its impact on pre-Cenozoic floristic provincialism. Australian Journal of Botany 49 (3): 271-300. https://doi.org/10.1071/BT00023.

Millioud, M.E. 1969. Dinoflagellates and acritarchs from some western European lower cretaceous type localities. Proceedings of First International Conference on Planktonic Microfossils, Geneva (1967) 2: 420-434.

Morgan, R. 1979. Palynostratigraphy of the Australian Early and middle Cretaceous. Geological Survey of New South Wales, Paleontology Memoir 18: 1-153.

Nagendra, R., B.K. Kannan, G. Sen, H. Gilbert, D. Bakkiaraj, A.N. Reddy, and B. C. Jaiprakash. 2011. Sequence surfaces and paleobathymetric trends in Albian to Maastrichtian sediments of Ariyalur area, Cauvery Basin, India. Marine and Petroleum Geology 28 (4): 895-905. https://doi.org/10.1016/j. marpetgeo.2010.04.002.

Oosting, A., H. Leereveld, G. Dickens, R. Henderson, and H. Brinkhuis. 2006. Correlation of Barremian-Aptian (mid-cretaceous) dinoflagellate cyst assemblages between the tethyan and austral realms. Cretaceous Research 27 (6): 792-813 https://doi.org/10.1016/j.cretres- .2006.03.012.

Powell, C.M., S. Roots, and J. Veevers. 1988. Pre-breakup continental extension in east Gondwanaland and the early opening of the eastern Indian ocean. Tectonophysics 155 (1-4): 261-283. https://doi.org/10. 1016/0040-1951(88)90269-7.

Prabhakar, K. 1993. Evolution of southern part of Indian east coast basin. Journal of Geological Society of India 41: 215-230.

Prasad, B., and B. Pundir. 1999. Biostratigraphy of the exposed Gondwana and cretaceous rocks of Krishna-Godavari Basin, India. Journal of Paleontological Society of India 44: 91-117.
Rangaraju, M., A. Agarwal, and K. Prabhakar. 1993. Tectono-stratigraphy, structural styles, evolutionary model and hydrocarbon habitat, Cauvery and Palar basins. In Proceedings of Second Seminar on Petroliferous Basins of India 1: 371-388.

Rao, G. 2001. Sedimentation, stratigraphy and petroleum potential of Krishna-Godavari Basin, east coast of India. AAPG Bulletin 85 (9): 16231643.

Sarjeant, W.A.S. 1966. Dinoflagellate cysts with Gonyaulax-type tabulation. In Studies on Mesozoic and Cainozoic dinoflagellate cysts; British Museum (Natural History) Geology, Bulletin, Supplement, ed. R.J. Davey, C. Downie, W.A.S. Sarjeant, and G.L. Williams, vol. 3, 107-156.

Sarjeant, W.A.S. 1985. The german Aptian dinoflagellate cysts of Eisenack (1958): A restudy. Review of Palaeobotany and Palynology 45 (1-2): $47-$ 106. https://doi.org/10.1016/0034-6667(85)90065-X.

Singh, I.B., and A.S.R. Swamy. 2006. Delta sedimentation: East Coast of India, 392. Dehradun: Technology Publications.

Stover, L., and R. Helby. 1987. The Jurassic dinoflagellate omatia and allied genera. Association of Australasian Palaeontologists Memoir 4: 143-158.

Stover, L.E., H. Brinkhuis, S.P. Damassa, L. De Verteuil, R.J. Helby, E. Monteil, and A.D. Partridge. 1996. Mesozoic-tertiary dinoflagellates, acritarchs and prasinophytes. Palynology: Principles and Applications 2: 641-750.

Tyson, R.V. 1995. Abundance of organic matter in sediments: TOC, hydrodynamic equivalence, dilution and flux effects. In Sedimentary organic matter, 81-118. Dordrecht: Springer publication. https://doi.org/ 10.1007/978-94-011-0739-6_5.

Veevers, J., C.M. Powell, and S. Roots. 1991. Review of seafloor spreading around Australia. i. Synthesis of the patterns of spreading. Australian Journal of Earth Sciences 38 (4): 373-389. https://doi.org/10.1080/ 08120099108727979.

\section{Publisher's Note}

Springer Nature remains neutral with regard to jurisdictional claims in published maps and institutional affiliations.

\section{Submit your manuscript to a SpringerOpen ${ }^{\circ}$ journal and benefit from:}

- Convenient online submission

Rigorous peer review

- Open access: articles freely available online

- High visibility within the field

- Retaining the copyright to your article

Submit your next manuscript at $\boldsymbol{\nabla}$ springeropen.com 